\title{
ENTROPİ VE MAİRCA YÖNTEMİYLE TÜRK KATILIM BANKALARININ FINANSAL PERFORMANS SIRALAMASI
}

\author{
Selahattin BEKTAŞ*
}

Makale Geliş Tarihi-Received: 24.07.2020

Makale Kabul Tarihi-Accepted: 25.01.2021

DOI: 10.37093/ijsi.950553

\section{ÖZ}

İslami bankacılık olarak ifade edilebilen katılım bankacılığı, faizsiz bankacılık olarak da bilinmektedir. Katılım bankacıllğı sektörü ilk olarak 1980'li yıllarda ortaya çıkmıştır. Katılım bankacılığı sektörü, Türk bankacılık sektörünün tamamlayıcısıdır. Bundan dolayı bu sektörün performans analizinin ölçülmesi daha da önemli hale gelmiştir. Geleneksel bankacılık sisteminden farkı ise faaliyette bulunduğu bankacılık işlemlerini faizsizlik prensibine dayandırarak yapmasıdır. Türk bankacllk sisteminde tamamlayıcı bir unsur olan katılım bankacilı̆̆ sektörü devletin desteğiyle hizh bir gelişim göstermişsir. Bu çalışmanın amacı, Türk bankacıllk sistemi içinde faaliyette bulunan katılım bankalarının 2018-2019 yıllan için finansal performanslarını ölçme ve sıralamaktır. Bundan dolayı Türk bankacıllk sektöründeki altı katılım bankası analize dahil edilmiştir. Bu çalışmada katılım bankalarının finansal performanslarım ölçmek için Entropi ve Mairca yöntemi ortak kullanılmıştır. Katılım bankalarının finansal performans ölçümünde kullanılması için altı kriter belirlenmiştir. Bu kriterler, Toplam Aktifler, Toplam Krediler ve Alacaklar, Toplam Mevduatlar, Toplam Öz kaynaklar, Şube Sayısı ve Çalışan Sayıları olarak belirlenmiştir. Yapılan

* Doktora Öğrencisi, (100/2000 Bursiyeri, Öncelikli Alanı: Katılım Bankacılığı) Bursa Uludă̆ Üniversitesi, Sosyal Bilimler Enstitüsü, İktisat Anabilim Dall, Bursa/Türkiye.selahattinbektas@uludag.edu.tr, ORCID: https://orcid.org/00000001-6285-8318. 


\section{Selahattin BEKTAŞ}

analiz sonucuna göre 2018 yllında en iyi performansl gösteren banka Ziraat Katılım Bankasıdır. İkinci en iyi performansı gösteren banka Türkiye Finans Katılım Bankasıdır. Üçüncü en iyi performansı gösteren bankada Kuveyt Türk Katılım bankasıdır. 2019 yılında ise en iyi finansal performansa sahip ilk üç banka strasıyla, Kuveyt Türk Katılım Bankası, ikinci en iyi Ziraat Katılım Bankası, üçüncü en iyi finansal performansı ise Vakıf Katılım Bankası göstermiştir.

Anahtar Kelimeler: Katılım Bankacılığı, Faizsiz Bankacılık, Performans Analizi, Entropi Yöntemi, Mairca Yöntemi.

Jel Kodu: B26, G20, G21.

IJSI 14/1 


\title{
FINANCIAL PERFORMANCE RANKING OF TURKISH PARTICIPATION BANKS BY ENTROPY AND MAIRCA METHOD
}

\begin{abstract}
Participation banking, also referred to as Islamic banking, is also known as interest-free banking. The participation banking sector emerged in the 1980s. The participation banking sector is a complement to the Turkish banking sector. Therefore, measuring the performance analysis of this sector has become even more important. The difference from the traditional banking system is that it performs its banking transactions on the basis of the interest-free principle. The participation banking sector, which is a complementary element in the Turkish banking system, has developed rapidly with the support of the state. The purpose of this study is to measure and rank the financial performance of participation banks operating in the Turkish banking system for 2018-2019. Therefore, six participation banks in the Turkish banking sector are included in the analysis. In this study, Entropy and Mairca method were used jointly to measure the financial performance of participation banks. Six criteria have been determined for the use of participation banks in financial performance measurement. These criteria are determined as Total Assets, Total Loans and Receivables, Total Deposits, Total Equity, Number of Branches and Number of Employees. According to the results of the analysis, the best shows performing bank in 2018 is Ziraat Participation Bank. The second the best performing bank is Turkey Finans Participation Bank. The third best performing bank is Kuveyt Türk Participation bank.
\end{abstract}

Keywords: Participation Banking, Interest-Free Banking, Performance Analysis, Entropy Method, Mairca Method.

Jel Code: B26, G20, G21. 


\section{Gíriş}

Reel sektör ve finansal sektörü birbirine bağlamada köprü görevi üstlenen banka ve bankacılık sektörü makro-ekonomik manada analiz için önemli bir konu olma durumunu hala korumaktadır. Tasarruf veya fon fazlasını atıl olarak ellerinde bulunduranların mevduatların, optimal yatırımlara sorunsuz bir şekilde aktarılması sürecinde baş rol alan bankaların, bankacılık faaliyetlerini etkin ve verimli bir şekilde yerine getirmeleri bankacılık sektörünün yanı sıra makro düzeyde de ekonomik performans ve rekabet için çok önemli hale gelmiştir (Bektaş, Seki, 2018: 198).

İslami bankacılık adıyla anılan katılım bankacılığı, faizsiz bankacılık olarak da ifade edilmektedir. Söz konusu bankalar, faize karşı duyarlı olan inanç hassasiyeti olan insanların dünya görüşlerinden ihtiyaç hasıl olduğu için doğmuştur. Bu bankalar, bankacıllı işlemlerini yerine getirirken faizsizlik prensibine dayanarak işlemleri yapmaktadır. Söz konusu bankalar, mevduat fazlası olanlardan mevduat açığı olanlara ihtiyaç duyduğu mevduatı sağlayarak bir aracı görevi de ifa ederler (Gündoğdu, 2018: 202).

1980'li yıllarda henüz banka statüsünde olmadığından ötürü, Özel Finans Kurumları (ÖFK) adı altında bankacılık faaliyetlerini sürdürmüşlerdir. Ticari bankalardan önemli bir farkı, katılım bankalarının kâra ve zarara katılmalarıdır. Bundan dolayı 2005 yılından itibaren statüsü "Banka" ve ismi de "Katılım Bankası" olarak değişmiş ve günümüzde de bankacılık faaliyetlerini halen bu statü ve isimle ifa etmektedirler.

2019 yılı aralık ayı itibarıyla Türkiye'de faaliyet içinde olan altı adet katılım bankası mevcuttur. Türk bankacılık sektörünün adeta tamamlayıcı unsuru olan katılım bankacılığı sektörü her geçen yıl giderek payını artırarak güçlenirken, devlet bankalarının da bu işe girişmeleri dengeleri değiştirmiş ve sektörün dinamiklerini artırmıştır. Dolayısıyla değişen dengelerin yanı sıra artan rekabet ortamından kaynaklı olarak söz konusu bankacılık sektöründe bulunan katılım bankalarının finansal performanslarının belirlenmeleri önem arz etmektedir. 
Entropi ve Mairca Yöntemiyle Türk Katılım Bankalarınn

Finansal Performans Stralamast

Tablo 1: Katılım ve Konvansiyonel Bankacılık Sektörü Başlıca Finansal Büyükleri.

\begin{tabular}{|c|c|c|c|c|c|c|c|}
\hline \multicolumn{8}{|c|}{$\begin{array}{l}\text { KATILIM BANKALARI VE BANKACILIK SEKTÖRÜ BAŞLICA FİNANSAL } \\
\text { BÜYÜKLÜKLERİ (Mio TL- ARALIK 2019) }\end{array}$} \\
\hline \multirow{2}{*}{\multicolumn{2}{|c|}{ Finansal Başlıklar }} & \multicolumn{3}{|c|}{ Katılım Bankaları } & \multicolumn{3}{|c|}{ Bankacılık Sektörü } \\
\hline & & Ara.19 & Ara.18 & $\begin{array}{c}\text { Değisisim } \\
(\%)\end{array}$ & Ara.19 & Ara.18 & $\begin{array}{l}\text { Değisisim } \\
(\%)\end{array}$ \\
\hline \multirow{4}{*}{$\begin{array}{l}\text { TOPLANAN } \\
\text { FONLAR** }\end{array}$} & TP & 91.145 & 60.626 & 50,3 & 1.267.073 & 1.054 .572 & 20,2 \\
\hline & YP & 106.533 & 67.790 & 57,2 & 1.226 .609 & 954.893 & 28,5 \\
\hline & YP-MADEN & 18.305 & 8.804 & 107,9 & 82.722 & 41.701 & 98,4 \\
\hline & TOPLAM & 215.983 & 137.220 & 57,4 & 2.576 .404 & 2.051 .166 & 25,6 \\
\hline \multicolumn{2}{|c|}{ KULLANDIRILAN FONLAR *** } & 149.475 & 124.562 & 20 & 2.739 .736 & 2.465 .582 & 11,1 \\
\hline \multicolumn{2}{|c|}{$\begin{array}{l}\text { TAKİPTEKİ ALACAKLAR } \\
\text { (BRÜT) }\end{array}$} & 7.763 & 5.050 & 53,7 & 150.108 & 96.611 & 55,4 \\
\hline \multicolumn{2}{|l|}{ TOPLAM AKTIF } & 284.450 & 206.806 & 37,5 & 4.491 .708 & 3.867 .135 & 16,2 \\
\hline \multicolumn{2}{|l|}{ ÖZ VARLIK } & 21.762 & 16.780 & 29,7 & 492.384 & 421.185 & 16,9 \\
\hline \multicolumn{2}{|l|}{ NET KAR } & 2.433 & 2.123 & 14,6 & 49.753 & 53.522 & -7 \\
\hline \multicolumn{2}{|c|}{ PERSONEL SAYISI } & 16.040 & 15.654 & 2,5 & 204.626 & 207.716 & $-1,5$ \\
\hline \multirow{3}{*}{ ŞUBE SAYISI } & YURTİÇİ & 1.176 & 1.120 & 5 & 11.300 & 11.493 & $-1,7$ \\
\hline & YURTDIŞI & 3 & 2 & 50 & 74 & 72 & 2,8 \\
\hline & TOPLAM & 1.179 & 1.122 & 5,1 & 11.374 & 11.565 & $-1,7$ \\
\hline
\end{tabular}

Kaynak: (TKBB, 2020).

Aşağıda Tablo 2' de katılım bankalarının sektördeki payları 2018-2019 karşılaştırmalı olarak verilmiştir.

Tablo 2: Katılım Bankalarının Sektör Payları.

\begin{tabular}{|l|c|c|}
\hline & 2019/Aralık & $\mathbf{2 0 1 8}$ \\
\hline TOPLANAN FONDA & 8,4 & 6,7 \\
\hline KULLANDIRILAN FONDA & 5,5 & 5,1 \\
\hline TOPLAM AKTIFTE & 6,3 & 5,3 \\
\hline ÖZ VARLIKTA & 4,4 & 4,0 \\
\hline NET KÂRDA & 4,9 & 3,9 \\
\hline
\end{tabular}

Kaynak: (TKBB, 2020). 
Bu çalışmanın amacı, 2018-2019 yılları arasında Türk bankacılık sektöründe bankacılık hizmetlerini ifa eden katılım bankalarının finansal performanslarını ölçüp sıralamaktır. Çalışmanın ilk bölümünü oluşturan giriş bölümünden sonra, ikinci bölüm olarak katılım bankalarının performans ölçümlerine dair yapılan seçilmiş çalışmalar özet olarak tabloda verilecektir. Bir sonraki bölümde çalışmanın amacını oluşturan performans analizinin yapıldığı veri, yöntem ve analiz sonuçlarına yer verilecektir. Son bölümde ise sonuç ve genel bir değerlendirme yapılacaktır.

\section{TÜRKIYYE'DE KATILIM BANKACILIĞININ GELIŞSIMI}

Tarihsel açıdan bakıldığında Türkiye'de katılım bankacılığı adına atılan kurumsal ilk adım olarak para vakıfları gelmektedir. 1456 yılında ilk kurumsal para vakfı uygulaması Fatih Sultan Mehmet Han tarafından hayata geçirilmiştir. 19. yy. sonuna kadar para vakıfları hizmetlerine devam etmiş sonrasında işlerliklerini yitirip yok olmuşlardır. Cumhuriyet tarihinde ise ilk katılım bankacılığı faaliyetini gerçekleştirmek üzere 1983 yılında ÖFK (Özel Finans Kurumları) kurulmuştur. ÖFK'lar 1985 yılından 2005 yılına kadar faaliyetlerini bu isim altında sürdürmüşlerdir (www.turkiyefinans.com.tr).

İsminde bulunan "özel" sözcüğüyle anlatılmak istenen kurumsal ya da kamu değil bir özel kimlikte oldukları, yine "finans" sözcüğüyle de anlatılmak istenen finansal işlem yapan bir finansal kurum kimliği taşıdıklarıdır (Kaya, 2010: 41). 2005 yılında mevzuat değişikliğine gidilerek banka statüsüne kavuşup "Katılım Bankası" ismi ile günümüzde de hala faaliyetlerini sürdürmektedirler (www.turkiyefinans.com.tr).

Türkiye'de kurulan katılım bankalarını ilkleri (ÖFK adı altında), 1985 yılında Albaraka Türk Finans Kurumu ve Faisal Finans Kurumu olmuştur. Dört yıl sonrasında yani 1989 yılında ise Kuveyt Türk Evkaf Finans Kurumu kurulmuştur. Peşi sıra 2 y1l geçtikten sonra 1991 yılında Anadolu Finans Kurumu, dört yıl sonrasında 1995'de İhlas Finans Kurumu, bir yıl sonrasinda 1996 yllında ise Asya Finans Kurulmuştur. Faisal Finansı Ülker grubunun devir alması sonrası ismi değiştirilerek Family Finans olarak faaliyetlerine devam ederken 2005 yılında Anadolu Finans Kurumuyla birleşme kararı alarak adını 
Türkiye Finans Katılım Bankası olarak değiştirmiştir (Sümer, Onan, 2015: 299-300).

Özellikle devletinde bu alanda çalışmalar başlatması ve sektöre katkılar sunması adına 2015 yılında ilk kamu katılım bankası statüsünde Ziraat Katılım Bankası faaliyete geçmiştir. Hemen ardında bir yıl sonra ikinci kamu katılım bankası olarak Vakıf Katılım Bankası faaliyete geçirilmiştir. Son olarak 2019 yılında faaliyete geçen üçüncü kamu katılım bankası ise Emlak Katılım Bankası olarak gerçekleşmiştir (https:/ / www.tkbb.org.tr).

Tablo 3: Türkiye' de Kurulan Katılım Banklarının Faaliyet Yılları.

\begin{tabular}{|c|l|}
\hline 1985 & $\begin{array}{l}\text { Albaraka Finans ve Faisal Finans Kurumlarının } \\
\text { faaliyete geçmesi. }\end{array}$ \\
\hline 1989 & $\begin{array}{l}\text { Kuveyt Türk Evkaf finans Kurumunun } \\
\text { faaliyete geçmesi. }\end{array}$ \\
\hline 1991 & $\begin{array}{l}\text { Anadolu Finans Kurumunun faaliyete } \\
\text { geçmesi. }\end{array}$ \\
\hline 1995 & İhlas Finans Kurumunun faaliyete geçmesi. \\
\hline 1996 & Asya Finans Kurumunun faaliyete geçmesi. \\
\hline 2001 & İhlas Finans Kurumunun Iflası. \\
\hline 2001 & $\begin{array}{l}\text { Faisal Finans'ın devri ve Family Finans'ın } \\
\text { faaliyete geçmesi. }\end{array}$ \\
\hline 2005 & $\begin{array}{l}\text { Family Finans'ın Anadolu Finans ile birleşerek } \\
\text { Türkiye Finans Katılım Bankası faaliyete } \\
\text { geçmesi. }\end{array}$ \\
\hline 2015 & Ziraat Katılım Bankası faaliyete geçti. \\
\hline 2016 & Vakıf Katılım Bankası faaliyete geçti. \\
\hline 2019 & Emlak Katılım Bankası faaliyete geçti. \\
\hline
\end{tabular}

Kaynak: (Sümer ve Onan, 2015: 299-300).

\section{LITERATÜR}

Çalışmanın bu kısmında katılım bankalarının performans ölçümlerine dair yapılmış olan ve literatürde yer alan bazı seçilmiş çalışmalar Tablo halinde 2010-2020 dönemi için özetlenmiştir. Literatür 
Tablosundan anlaşıldığı üzere çok kriterli karar verme yöntemleri katılım bankalarının performans ölçümlerinde ele alınan kriterlerin sayıca fazlalığı ve bundan dolayı oluşan karmaşıklıktan ötürü sıkça kullanılmaktadır.

Ayrıca Çok Kriterli Karar Verme Yöntemlerinden biri olan Mairca yöntemi kullanılarak mevduat bankası performans ölçümü ile ilgili yapılan çalışmalara rastlanılmamıştır. Literatürde bu yöntem ile mevduat bankalarının performans ölçümünü yapan çalışma olarak Ayçin ve Orçun (2019) ile Ayçin ve Güçlü (2020) örnek olarak gösterilebilir.

Dolayısıyla literatürde bu yöntemle performans ölçümü yapan çalışma eksikliğinden hareketle bu çalı̧̧manın da söz konusu çalışmadan esinlenerek bu alandaki boşluğu bir nebze dolduracağ ${ }_{1}$ ve katkı yapacağı düşünülmektedir.

Tablo 4: Katılım Bankaların Finansal Performanslarının Ölçümüne İlişkin Literatür Özet Tablo.

\begin{tabular}{|c|l|l|}
\hline $\begin{array}{c}\text { Çetin ve Bıtırak } \\
(2010)\end{array}$ & $\begin{array}{l}\text { 2005:12/2007:12 dönemleri } \\
\text { arasında katılım bankaları ve } \\
\text { ticari bankaların } \\
\text { performanslarının analizi } \\
\text { yapılmıştır. AHS yöntemi } \\
\text { kullanılmıştır. }\end{array}$ & $\begin{array}{l}\text { Çalışmanın sonucunda ise Ticari } \\
\text { bankalarda Akbank, katılım } \\
\text { bankalarında Bank Asya ise en iyi } \\
\text { performansa sahip bankalar olarak } \\
\text { bulunmuştur. }\end{array}$ \\
\hline $\begin{array}{c}\text { Yayar ve Baykara } \\
\text { (2012) }\end{array}$ & $\begin{array}{l}\text { 2005-2011 dönemleri arasında } \\
\text { katılım bankalarının } \\
\text { faaliyetlerinin performanslarını } \\
\text { Topsis yöntemiyle ölçmüşlerdir. }\end{array}$ & $\begin{array}{l}\text { Çalışmanın sonucunda ise Albaraka en } \\
\text { etkin banka, Bank Asya ise en verimli } \\
\text { banka olarak bulunmuştur. Kuveyt } \\
\text { Türk' ise bir miktar etkinlik ve } \\
\text { verimlilik artışı saptanmıştır. }\end{array}$ \\
\hline Er ve Uysal (2012) & $\begin{array}{l}\text { 2005-2010 dönemleri arasında } \\
\text { ticari bankaların ve katılım } \\
\text { bankalarının performanslarını } \\
\text { karşıllaştırmalı olarak analiz } \\
\text { etmişlerdir. Çalışmada VZA } \\
\text { yöntemi kullanılmıştır. }\end{array}$ & $\begin{array}{l}\text { Sonuç olarak CCR modeline göre9 } \\
\text { mevduat 2 katılım bankası, BCC } \\
\text { modeline göre ise 13 mevduat 3 katılım } \\
\text { bankasının etkin ve verimli olduğu } \\
\text { saptanmıştır. Genel etkinliğe incelenen } \\
\text { dönem boyunca bakıldığında katılım } \\
\text { bankalarının mevduat bankalarına göre } \\
\text { daha etkin olduğu ortaya çımıştır. }\end{array}$ \\
\hline
\end{tabular}


Entropi ve Mairca Yöntemiyle Türk Katılım Bankalarnın Finansal Performans Stralaması

Tablo 4. (Devamı)

\begin{tabular}{|c|c|c|}
\hline Doğan (2013) & $\begin{array}{l}2005-2011 \text { yılları arasında } \\
\text { konvansiyonel bankaların ve } \\
\text { katılım bankalarının } \\
\text { performans analizini t- testi ile } \\
\text { gerçekleştirmiştir. }\end{array}$ & $\begin{array}{l}\text { Yapılan çalışmada sonuç olarak } \\
\text { konvansiyonel bankaların geleneksel } \\
\text { bankalara göre likidite, borç ödeme gücü } \\
\text { ve sermaye yeterliliği kriterlerinde daha } \\
\text { yüksek, risklilikte ise daha düşük olduğu } \\
\text { belirlenmiştir. Katılım bankaları ve } \\
\text { konvansiyonel bankların karlılıkları } \\
\text { arasında istatistiksel anlamlılık } \\
\text { bulunmuştur. }\end{array}$ \\
\hline $\begin{array}{c}\text { Altan ve } \\
\text { Candoğan (2014) }\end{array}$ & $\begin{array}{l}2012 \text { yılının 3. Çeyreği için } \\
\text { katılım bankalarının } \\
\text { performansları sonuçları } \\
\text { belirlenmeye ve } \\
\text { karşılaştırılmaya çalışılmıştır. } \\
\text { Gri ilişkisel analiz ve } \\
\text { geleneksel performans ölçüm } \\
\text { yöntemleri kullanılmıştır. }\end{array}$ & $\begin{array}{l}\text { Sonuç olarak ise çalışmada hem } \\
\text { geleneksel hem de Gri ilişkisel analiz } \\
\text { yöntemiyle elde edilen performans } \\
\text { değerlerinin farklı olduğu ortaya } \\
\text { çıkarılmıştır. }\end{array}$ \\
\hline Özgür (2008) & $\begin{array}{l}\text { 2001-2005 dönemi için katılım } \\
\text { bankalarının } \\
\text { performanslarının VZA } \\
\text { yöntemi ile ölçülmüştür. }\end{array}$ & $\begin{array}{l}\text { Yapılan analiz sonucunda ise en iyi } \\
\text { etkinliğe sahip banka Albaraka Türk } \\
\text { olduğu bulunmuştur. }\end{array}$ \\
\hline $\begin{array}{l}\text { Gümüş ve } \\
\text { Nalbantoğlu } \\
\text { (2015) }\end{array}$ & $\begin{array}{l}\text { 2002-2013 dönemi arası için } \\
\text { katılım bankaları ve diğer } \\
\text { banka gruplarının } \\
\text { performansları ölçülmüştür. } \\
\text { Çalışmada Topsis yöntemi } \\
\text { kullanılmıştır. }\end{array}$ & $\begin{array}{l}\text { Çalışma sonucuna göre Yerli özel } \\
\text { sermayeli bankalar en iyi performansı } \\
\text { sergilerken, kamu bankaları ikinci en iyi } \\
\text { performansa sahip grup olduğu, yabancı } \\
\text { bankalar zayıf bir performans sergileyen } \\
\text { grup olurken, katılım bankaları kötü } \\
\text { performans sergileyen banka grubu } \\
\text { olarak bulunmuştur. }\end{array}$ \\
\hline $\begin{array}{c}\text { Esmer ve Bağcı } \\
(2016)\end{array}$ & $\begin{array}{l}\text { 2005-2014 dönemi arasında } \\
\text { katılım bankalarının finansal } \\
\text { performansları ölçülmüştür. } \\
\text { Çalışmada Topsis yöntemi } \\
\text { kullanılmıştır. }\end{array}$ & $\begin{array}{l}\text { Çalışma sonucunda incelenen dönem için } \\
\text { en yüksek performansa sahip ve en karlı } \\
\text { banka olarak Bank Asya bulunmuştur. }\end{array}$ \\
\hline Ayrıçay vd (2017) & $\begin{array}{l}2016 \text { yılı } 4 \text {. Dönem için katılım } \\
\text { banklarının performanslarını } \\
\text { AHP ve GİA yöntemleriyle } \\
\text { ölçülmüştür. }\end{array}$ & $\begin{array}{l}\text { Çalışmadaki analiz sonucunda Vakıf } \\
\text { Katılım en iyi performansa sahipken, en } \\
\text { kötü performansa sahip banka ise } \\
\text { Albaraka Türk olarak belirlenmiştir. }\end{array}$ \\
\hline $\begin{array}{c}\text { Yuttadur ve } \\
\text { Demirbaş (2017) }\end{array}$ & $\begin{array}{l}\text { 2010-2016 dönemi arasında üç } \\
\text { katılım bankası ve üç mevduat } \\
\text { bankasının performansları t- } \\
\text { testi kullanılarak ölçülmüştür. }\end{array}$ & $\begin{array}{l}\text { Çalışma sonucunda katılım bankalarının } \\
\text { kârlılık bakımından mevduat bankalarına } \\
\text { göre daha yüksek performans ortaya } \\
\text { koydukları, likidite bakımından özellikle } \\
\text { likit aktiflerin kısa vadeli yükümlülükleri } \\
\text { bakımından daha } \\
\text { likit oldukları, ayrıca borçluluk oranı } \\
\text { bakımında da katılım bankalarının daha } \\
\text { borçlu yapıya sahip oldukları } \\
\text { belirlenmiştir }\end{array}$ \\
\hline
\end{tabular}


Selahattin BEKTAŞ

Tablo 4. (Devamı)

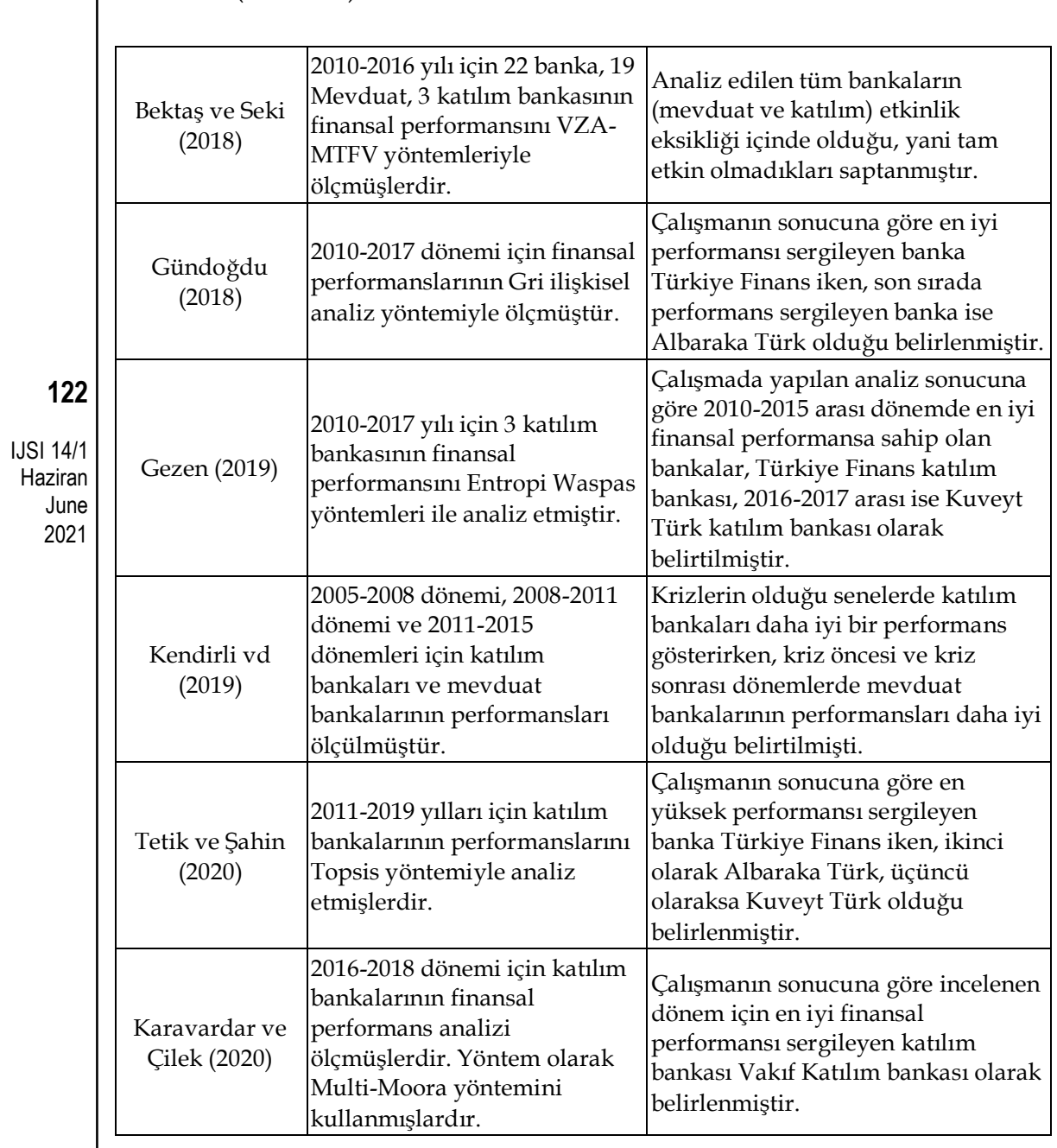




\section{VERİ SETİ VE YÖNTEM ${ }^{1}$}

\section{1. Çalışma Amacı ve Veri Seti}

Bu çalışmanın amacı, Türkiye'de 1980'lerden itibaren Özel Finans Kurumları (ÖFK) altında 2005 yılıyla beraber Katılım Bankacılığı statüsüyle bankacılık faaliyeti yürüten katılım bankalarının 2018-2019 dönemi için finansal performanslarını Çok Kriterli Karar Verme Yöntemlerinden (ÇKKV) olan Entropi ve Mairca Yöntemlerini kullanarak analiz etmektir.

TKBB (2019) verilerine göre, katılım bankacılığı sektöründe bankacılık faaliyetlerini yürüten 31 Aralık 2019 itibariyle 6 adet katılım bankası bulunmaktadır. Analiz dönemi 2018-2019 dönemini kapsadığından dolayı 2018 yılında beş adet katılım olduğu için beş katılım bankası analize dahil edilmiştir. Emlak Katılım Bankası 2018 yılında bankacılık faaliyetlerini yürütmek için izin almış olup 2018 yılında kurulmuştur, fakat yeterli derecede verisi olmadığı için 2018 yılında analiz kapsamı dişında tutulmuş olup, 2019 yılı için yeterli derecede verisi olduğundan analiz kapsamına dahil edilmiştir.

Bu çalışmada 2018-2019 yıllarını kapsayan verilerle yapılan analiz sonuçlar tablolar halinde karşılaştırmalı olarak analiz edilmiştir. Çalışmada kullanılan veri setinin oluşturulmasında katılım bankalarının yıllık olarak yayınladıkları konsolide olmayan faaliyet raporlarından istifade edilmiştir.

Çalışmanın analizinde dahil olan mevduat bankalarının finansal performanslarının ölçülmesinde ele alınan kriterlerin belirlenmesinde literatürde yer alan Ayçin ve Orçun (2019) Akçakanat vd. (2017) ve Ural vd. (2018) kullanmış oldukları kriterlerden istifade edilmiştir. Bu kriterler şunlardır:

* Toplam aktifler (C1)

* Toplam krediler ve alacaklar (C2)

1 Çok Kriterli Karar Verme Yöntemlerinden olan Entropi ve Mairca yöntemlerine ilişkin formül ve denklem notasyonları için Ayçin ve Orçun (2019)' dan yararlanılmıştır. 


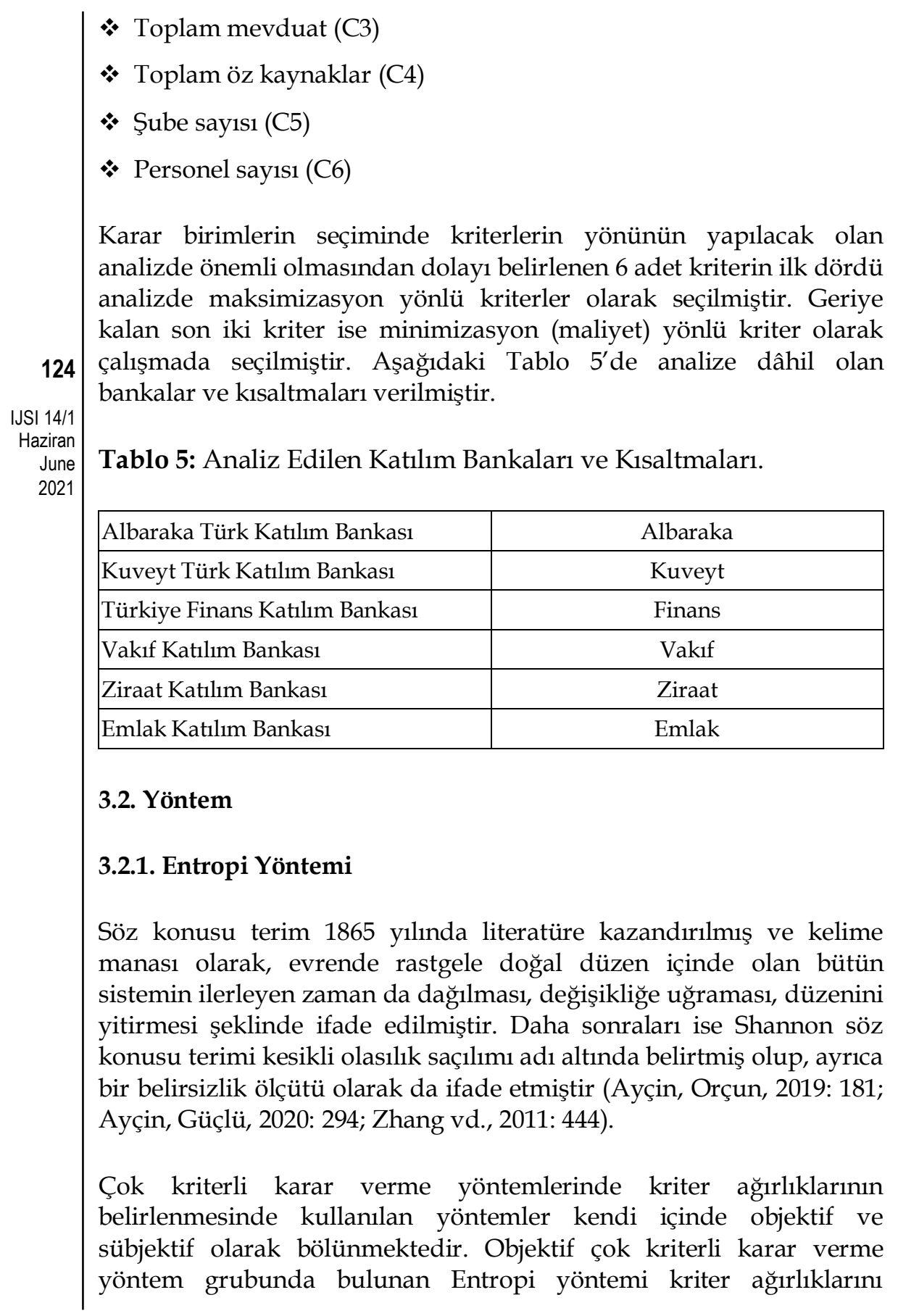


belirlemede bir tek karar matrisinin gerekli olması ve tüm işlemleri söz konusu matris ile yapmasından dolayı, yani hiçbir sübjektif ek bir kritere gerek duymaması gereği literatürde oldukça çok kullanılmaktadır. Söz konusu yöntemin uygulama aşaması dört kısımdan meydana gelir (Ayçin, Orçun, 2019: 181; Özdağoğlu vd., 2017: 349-347; Wang, Lee, 2009: 982; Erol, Ferrell, 2009: 1196-1197).

\section{İlk Aşama: Karar Matrisinin Oluşturulması:}

Yöntemin ilk kısminda $x_{i j}$ değerlerinden oluşan ve D ile simgelenen karar matrisi Eşitlik (1)'de gösterilen şekilde oluşturulur.

$$
D=\begin{gathered}
A_{1} \\
A_{2} \\
\vdots \\
A_{m}
\end{gathered}\left[\begin{array}{cccc}
x_{11} & x_{12} & \ldots & x_{1 n} \\
x_{21} & x_{22} & \ldots & x_{2 n} \\
\vdots & \vdots & \ldots & \vdots \\
x_{m 1} & x_{m 2} & \ldots & x_{m n}
\end{array}\right]
$$

Eşitlik (1)'de yer alan $x_{i j}$ değerleri, j. değerlendirme kriterine göre $\mathrm{i}$. alternatifin aldığı değerleri göstermektedir. (i, karar alternatifi sayısı $i=1,2, \ldots, m ; \mathrm{j}$ ise değerlendirme kriteri sayıs $1 j=1,2, \ldots ., n$ sayısı).

\section{İkinci Aşama: Karar Matrisinin Normalizasyonu:}

$\mathrm{Bu}$ kısımda karar problemlerinde yer alan farklı birimlere sahip kriterlere ilişkin değerler, normalizasyon işlemiyle [0,1] aralığında değer alacak şekilde standart bir hale getirilmelidir. Normalizasyon işlemi Eşitlik (2)'den yararlanılarak gerçekleştirilir.

$$
p_{i j}=\frac{x_{i j}}{\sum_{i=1}^{m} x_{i j}} \quad \forall i, j
$$

Eşitlik (2)'de yer alan $p_{i j}$ : değerleri, j. değerlendirme kriterine göre i. alternatifin aldığı normalize değeri göstermektedir.

\section{Üçüncü Aşama: Kriterlere İlişkin Entropi Değerlerinin Bulunması:}

$\mathrm{Bu}$ kısımda her bir değerlendirme kriterinin Entropi değerleri $\left(e_{j}\right)$, Eşitlik (3)'te gösterilen şekilde hesaplanır. 


$$
e_{i j}=-k \cdot \sum_{j=1}^{n} p_{i j} \cdot \ln \left(p_{i j}\right) \quad i=1,2, \ldots, m \text { ve } j=1,2, \ldots, n
$$

Eşitlik (3)'de yer alan k değeri $k=(\ln (m))^{-1}$ olarak tanımlanan sabit bir katsayıdır ve $0 \leq e_{j} \leq 1$ olacak şekilde değer alır. $e_{j}$ değeri, $\mathrm{j}$. kriterin belirsizlik ölçüsü ya da diğer bir ifadeyle Entropi değeri olarak tanımlanır.

\section{Dördüncü Aşama: Farklılaşma Derecelerinin Bulunması:}

$\mathrm{Bu}$ kısımda, bir önceki aşamada hesaplanan Entropi değerleri kullanılarak, farklılaşma dereceleri (degree of diversification) olan $d_{j}$ değerleri her bir kriter için Eşitlik (4)'de gösterilen şekilde hesaplanır.

$$
d_{j}=1-e_{j} \quad j=1,2, \ldots, n
$$

\section{Beşinci Aşama: Entropi Kriter Ağırlıklarının Hesaplanması:}

Yöntemin son kısmında her bir kriterin farklılaşma derecesini, toplam farklılaştırma derecesine oranlayarak kriterlerin ağırlık değerleri $\left(w_{j}\right)$ Eşitlik (5)'de gösterilen şekilde hesaplanır:

$$
w_{j}=\frac{d_{j}}{\sum_{j=1}^{n} d_{j}}
$$

\subsubsection{Mairca Yöntemi}

Söz konusu yöntem, Gigovic vd. tarafından literatüre kazandırılan çok kriterli karar verme yöntemlerinden biridir. Mairca (Multi Attributive İdeal-Real Comparative Analysis) yönteminin dayandığı temel ideal ve ampirik derecelendirmelerin aralarındaki boşlukları tanımlamaya dayalı bir yöntemdir. Kriterlerin her biri için boşlukların toplanmasıyla, alternatifler için toplam boşluklar hesaplanır. İlgili hesaplamalar sonucunda elde edilen boşluklar toplam, boşlukları en az olan alternatif en iyi alternatif olarak seçilir (Gigoviç vd., 2016: 11; Pamucar vd., 2017: 58; Ayçin, Orçun, 2019: 182; Ayçin, Güçlü, 2020: 296). 
Çok kriterli karar verme yöntemlerinden biri olan Mairca yöntemi, yedi aşamadan meydana gelmektedir (Pamucar vd., 2018: 1646-1648).

\section{İlk Aşama: Başlangıç Karar Matrisinin (X) Oluşturulması}

Her bir alternatiften $\left(A_{i}\right)$ elde edilen kriter $\left(C_{j}\right)$ değerleri Eşitlik (8)'de gösterilmiştir.

$$
X=\quad\left[\begin{array}{cccc}
C_{1} & C_{2} & \ldots & C_{n} \\
x_{11} & x_{12} & \ldots & x_{1 n} \\
x_{21} & x_{22} & \ldots & x_{2 n} \\
\vdots & \vdots & \ddots & \vdots \\
x_{m 1} & x_{m 2} & \ldots & x_{m n}
\end{array}\right] \quad \text { (8) }\left[\begin{array}{l}
127 \\
\text { IJSI 14/1 } \\
\text { Haziran } \\
\text { June } \\
2021
\end{array}\right.
$$

İkinci Aşama: Alternatiflerin Önceliklerinin Belirlenmesi

Karar vericinin alternatif seçim sürecinde bir önceliğin olmaması yöntemin bir varsayımıdır. $m$ toplam alternatif sayısı olmak üzere $i$. alternatifin önceliği $P_{A i}$ Eşitlik (9)'da gösterilen şekilde hesaplanır.

$$
P_{A i}=\frac{1}{m} ; \quad \sum_{i=1}^{m} P_{A i}=1 \quad i=1,2, \ldots, m
$$

Karar verici her alternatife eşit uzaklıktadır. Bu nedenle bütün öncelikler Eşitlik (10)' da gösterildiği üzere, eşittir.

$$
P_{A 1}=P_{A 2}=\cdots=P_{A m}
$$

Üçüncü Aşama: Teorik Derecelendirme Matrisinin $\left(\mathbf{T}_{\mathbf{p}}\right)$ Oluşturulmasi

Matrisin elemanları $\left(t_{p i j}\right)$ Eşitlik (11)'de gösterildiği üzere, alternatiflerin öncelikleri $\left(P_{A i}\right)$ ile kriter ağırlıklarının $\left(w_{j}\right)$ çarpılması ile hesaplanir. 


$$
\boldsymbol{T}_{\boldsymbol{p}}=\left[\begin{array}{cccc}
P_{A 1} \cdot w_{1} & P_{A 1} \cdot w_{2} & \ldots & P_{A 1} \cdot w_{n} \\
P_{A 2} \cdot w_{1} & P_{A 2} \cdot w_{2} & \ldots & P_{A 2} \cdot w_{n} \\
\vdots & \vdots & \ddots & \vdots \\
P_{A m} \cdot w_{1} & P_{A m} \cdot w_{2} & \ldots & P_{A m} \cdot w_{n}
\end{array}\right]
$$

\section{Dördüncü Aşama: Gerçek Derecelendirme Matrisinin $\left(T_{r}\right)$}

\section{Tanımlanması}

$T_{r}$ matrisinin elde edilebilmesi için teorik derecelendirme matrisi $T_{p}$ ile başlangıç karar matrisi $X^{\prime}$ ten faydalanılır. Matris elemanları, maksimizasyon yönlü kriterler için Eşitlik (12), minimizasyon yönlü kriterler için ise Eşitlik (13)'ten yararlanılarak hesaplanmalıdır.

$$
\begin{aligned}
& t_{r i j}=t_{p i j} \cdot\left(\frac{x_{i j}-x_{i j}^{-}}{x_{i j}^{+}-x_{i j}^{-}}\right) \\
& t_{r i j}=t_{p i j} \cdot\left(\frac{x_{i j}-x_{i j}^{+}}{x_{i j}^{-}-x_{i j}^{+}}\right)
\end{aligned}
$$

$x_{i j}^{+} \quad$ kriterin alternatiften aldığ 1 en büyük değeri $\left(x_{i j}^{+}=\right.$ $\left.\max \left(x_{1}, x_{2}, \ldots, x_{m}\right)\right), x_{i j}^{-}$ise kriterin alternatiften aldığ1 en küçük değeri $\left(x_{i j}^{-}=\min \left(x_{1}, x_{2}, \ldots, x_{m}\right)\right)$ ifade etmektedir.

Hesaplamalar sonucunda elde edilecek olan Gerçek derecelendirme matrisi Eşitlik (14)'te gösterilmiştir.

$$
\begin{aligned}
& \begin{array}{lllll}
C_{1} & C_{2} & \ldots & C_{n}
\end{array} \\
& {\left[\begin{array}{cccc}
t_{r 11} & t_{r 12} & \ldots & t_{r 1 n} \\
t_{r 21} & t_{r 22} & \ldots & t_{r 2 n} \\
\vdots & \vdots & \ddots & \vdots \\
t_{r m 1} & t_{r m 2} & \ldots & t_{r m n}
\end{array}\right]}
\end{aligned}
$$

\section{Beşinci Aşama: Toplam Boşluk Matrisinin (G) Hesaplanması}

Boşluk Matrisi $(G)$ Eşitlik (15) yardımıyla, teorik derecelendirme matrisi $\left(T_{p}\right)$ ile gerçek derecelendirme matrisinin $\left(T_{r}\right)$ farkı alınarak Eşitlik (16)'da gösterilen şekilde elde edilir.

$$
g_{i j}=t_{p i j}-t_{r i j} \quad g_{i j} \in[0, \infty)
$$




$$
G=T_{p}-T_{r}=\left[\begin{array}{cccc}
g_{11} & g_{12} & \cdots & g_{1 n} \\
g_{21} & g_{22} & \cdots & g_{2 n} \\
\vdots & \vdots & \ddots & \vdots \\
g_{m 1} & g_{m 2} & \cdots & g_{m n}
\end{array}\right]
$$

\section{Altıncı Aşama: Toplam Boşluğun Alternatifler ile Tanımlanması}

Eğer bir kriter $\left(C_{j}\right)$ için bir alternatifin $\left(A_{i}\right)$ teorik derecesi $\left(t_{p i j}\right)$ ile gerçek derecesi $\left(t_{r i j}\right)$ eşit ve sıfırdan farklı bir değer almışsa, boşluk sıfır olacaktır $\left(g_{i j}=0\right)$. Bu durumda bu kriter $\left(C_{j}\right)$ için bu alternatif $\left(A_{i}\right)$ ideal alternatif $\left(A_{i}^{+}\right)$olacaktır. Eğer bir kriter $\left(C_{j}\right)$ için bir alternatifin $\left(A_{i}\right)$ teorik derecesi $\left(t_{p i j}\right)$ ile gerçek derecesi $\left(t_{r i j}\right)$ sıfıra eşitse $\left(t_{p i j}=t_{r i j}=g_{i j}=0\right)$. Bu durumda bu kriter $\left(C_{j}\right)$ için bu alternatif $\left(A_{i}\right)$ en kötü alternatif $\left(A_{i}^{-}\right)$olacaktır.

Yedinci Aşama: Alternatiflerin Nihai Kriter Fonksiyonlarının Değerinin $\left(\mathbf{Q}_{\mathbf{i}}\right)$ Hesaplanması

Kriter fonksiyonlarının değeri, her bir alternatif için Eşitlik (17)'den yararlanılacak şekilde hesaplanır.

$$
Q_{i}=\sum_{j=1}^{n} g_{i j}, \quad i=1,2, \ldots, m
$$

$Q_{i}$ değerleri küçükten büyüğe doğru sıralanarak alternatiflerin siralamaları elde edilir.

\subsection{Analiz Sonuçları}

Çalışmanın bu kısmında çok kriterli karar verme yöntemleriyle finansal performans analizinin gerçekleşebilmesi için çok kriterli karar verme yöntemlerinin bir parçası olan karar matrisi oluşturulmuştur. Söz konusu matris sonraki adımlarda da kullanıldığı için bir başlangıç aşaması olarak ifade edilir. Bu çalışmada ilk olarak analize dâhil edilen katılım bankalarının ilgili dönem itibariyle 2018-2019 yıllarına ait verilerden oluşturulan karar matrisi aşağıda Tablo 6'da ve Tablo 7 'de gösterilmiştir. 
Tablo 6: 2018 Yılına İlişkin Karar Matrisi.

\begin{tabular}{|l|c|c|c|c|c|c|}
\hline \multicolumn{7}{|c|}{ Karar Matrisi } \\
\hline BANKALAR & $\begin{array}{c}\text { Toplam } \\
\text { Aktifler }\end{array}$ & $\begin{array}{c}\text { Toplam } \\
\text { Krediler ve } \\
\text { Alacaklar }\end{array}$ & $\begin{array}{c}\text { Toplam } \\
\text { Mevduatlar }\end{array}$ & $\begin{array}{c}\text { Toplam } \\
\text { Ozkaynaklar }\end{array}$ & $\begin{array}{c}\text { Şube } \\
\text { Say1s1 }\end{array}$ & $\begin{array}{c}\text { Çalışan } \\
\text { Say1s1 }\end{array}$ \\
\hline Albaraka & 42.223 .652 & 25.173 .679 & 28.623 .473 & 3.261 .451 & 229 & 3.973 \\
\hline Kuveyt & 74.232 .325 & 44.168 .568 & 53.986 .278 & 5.438 .553 & 414 & 5.868 \\
\hline Finans & 47.052 .484 & 28.811 .246 & 26.862 .479 & 4.323 .181 & 306 & 2.315 \\
\hline Vakıf & 20.955 .512 & 13.321 .240 & 15.182 .406 & 1.527 .226 & 91 & 1.092 \\
\hline Ziraat & 22.188 .803 & 17.003 .830 & 15.151 .098 & 2.218 .584 & 80 & 1.042 \\
\hline
\end{tabular}

Kaynak: Yazar tarafından bankaların yıllık finansal raporlarından derlenmiştir.

Tablo 7: 2019 Yılına İlişkin Karar Matrisi.

\begin{tabular}{|l|c|c|c|c|c|c|}
\hline \multicolumn{7}{|c|}{ Karar Matrisi } \\
\hline BANKALAR & $\begin{array}{c}\text { Toplam } \\
\text { Aktifler }\end{array}$ & $\begin{array}{c}\text { Toplam } \\
\text { Krediler } \\
\text { ve } \\
\text { Alacaklar }\end{array}$ & $\begin{array}{c}\text { Toplam } \\
\text { Mevduatlar }\end{array}$ & $\begin{array}{c}\text { Toplam } \\
\text { Özkaynaklar }\end{array}$ & $\begin{array}{c}\text { Şube } \\
\text { Sayısi }\end{array}$ & $\begin{array}{c}\text { Çalışan } \\
\text { Sayısi }\end{array}$ \\
\hline Albaraka & 51.392 .368 & 30.637 .243 & 39.769 .408 & 3.821 .929 & 228 & 3.771 \\
\hline Kuveyt & 104.439 .345 & 55.218 .449 & 85.494 .387 & 6.821 .290 & 430 & 4.120 \\
\hline Finans & 52.427 .410 & 22.622 .518 & 39.974 .514 & 4.827 .079 & 310 & 2.205 \\
\hline Vakıf & 30.348 .784 & 18.588 .745 & 22.953 .215 & 1.960 .693 & 104 & 1.322 \\
\hline Ziraat & 36.392 .174 & 25.908 .664 & 25.457 .245 & 3.166 .828 & 93 & 1.129 \\
\hline
\end{tabular}

Kaynak: Yazar tarafından bankaların yıllık finansal raporlarından derlenmiştir.

Her iki yöntemde de kullanılacağı için analizin ilk bölümünde katılım bankalarının finansal performanslarının ölçülmesinde kullanılan kriterlerin önem ağırlıkları Entropi yöntemi vasıtası ile belirlenmiştir. Entropi metodunun ilk bölümünde Tablo 6 ve Tablo $7^{\prime}$ de hesaplanarak oluşturulan karar matrisleri Eşitlik (2)'den faydalanılarak normalize edilmiş ve hesaplama sonrası normalize edilmiş karar matrisleri oluşturulmuştur. Aşağıda Tablo $8^{\prime}$ de ve Tablo $9^{\prime}$ da normalize edilmiş karar matrisleri yer almaktadır. 
Entropi ve Mairca Yöntemiyle Türk Katılım Bankalarnın

Finansal Performans Siralaması

Tablo 8: 2018 Yılına İlişkin Normalize Edilmiş Karar Matrisi.

\begin{tabular}{|l|c|c|c|c|c|c|}
\hline \multicolumn{7}{|c|}{ Normalize Edilmiş Karar Matrisi } \\
\hline BANKALAR & $\begin{array}{c}\text { Toplam } \\
\text { Aktifler }\end{array}$ & $\begin{array}{c}\text { Toplam } \\
\text { Krediler ve } \\
\text { Alacaklar }\end{array}$ & $\begin{array}{c}\text { Toplam } \\
\text { Mevduatlar }\end{array}$ & $\begin{array}{c}\text { Toplam } \\
\text { Özkaynaklar }\end{array}$ & $\begin{array}{c}\text { Şube } \\
\text { Sayıs1 }\end{array}$ & $\begin{array}{c}\text { Çalışan } \\
\text { Sayısı }\end{array}$ \\
\hline Albaraka & 0,204 & 0,196 & 0,205 & 0,194 & 0,204 & 0,278 \\
\hline Kuveyt & 0,359 & 0,344 & 0,386 & 0,324 & 0,370 & 0,411 \\
\hline Finans & 0,228 & 0,224 & 0,192 & 0,258 & 0,273 & 0,162 \\
\hline Vakıf & 0,101 & 0,104 & 0,109 & 0,091 & 0,081 & 0,076 \\
\hline Ziraat & 0,107 & 0,132 & 0,108 & 0,132 & 0,071 & 0,073 \\
\hline
\end{tabular}

Kaynak: Yazarın hesaplamaları.

Tablo 9: 2019 Yılına İlişkin Normalize Edilmiş Karar Matrisi.

\begin{tabular}{|l|c|c|c|c|c|c|}
\hline \multicolumn{7}{|c|}{ Normalize Edilmiş Karar Matrisi } \\
\hline BANKALAR & $\begin{array}{c}\text { Toplam } \\
\text { Aktifler }\end{array}$ & $\begin{array}{c}\text { Toplam } \\
\text { Krediler ve } \\
\text { Alacaklar }\end{array}$ & $\begin{array}{c}\text { Toplam } \\
\text { Mevduatlar }\end{array}$ & $\begin{array}{c}\text { Toplam } \\
\text { Özkaynaklar }\end{array}$ & $\begin{array}{c}\text { Şube } \\
\text { Sayıs1 }\end{array}$ & $\begin{array}{c}\text { Çalışan } \\
\text { Sayısı }\end{array}$ \\
\hline Albaraka & 0,181 & 0,193 & 0,181 & 0,176 & 0,194 & 0,292 \\
\hline Kuveyt & 0,367 & 0,348 & 0,389 & 0,313 & 0,366 & 0,319 \\
\hline Finans & 0,184 & 0,143 & 0,182 & 0,222 & 0,264 & 0,171 \\
\hline Vakıf & 0,107 & 0,117 & 0,105 & 0,090 & 0,088 & 0,102 \\
\hline Ziraat & 0,128 & 0,163 & 0,116 & 0,145 & 0,079 & 0,087 \\
\hline
\end{tabular}

Kaynak: Yazarın hesaplamaları.

Sonraki kısımda, Eşitlik (3)'de verilen formül ile Tablo 8 'de ve Tablo $9^{\prime}$ da oluşturulan normalize karar matrisinin değerleri (Pij) çarpılarak toplanmıştır. Eşitlik (3)'de bir farklı değer daha yer almaktadır. Bu değer " $k$ " değeridir. Bu değerin hesaplanması karar alternatiflerinin doğal logaritması alınarak belirlenir. Çalışmanın analizinde 2018 yılı için beş, 2019 yılı için altı adet katılım bankası mevcuttur. Söz konusu değer, $\mathrm{k}=\left(\ln (\mathrm{m})^{-1}\right.$ aracılı̆̆ıyla, 2018 yılı için $\mathrm{k}=(\ln (5))^{-1}=0,621$ olarak bulunurken, 2019 yılı için ise bu değer yine aynı formül kullanılarak $\mathrm{k}=(\ln (6))^{-1}=0,558$ olarak hesaplanmıştır. Uygulanan hesaplamayla belirlenen entropi değerleri aşağıda Tablo 10'da ve Tablo 11'de gösterilmiştir. 
Tablo 10: 2018 Y1lı İçin Entropi Değerleri.

\begin{tabular}{|c|c|c|c|c|c|c|}
\hline \multicolumn{7}{|c|}{ Kriterlere İlişkin Entropi Değerleri } \\
\hline $\begin{array}{l}\text { Toplam } \\
\text { Aktifler }\end{array}$ & $\begin{array}{c}\text { Toplam } \\
\text { Krediler ve } \\
\text { Alacaklar }\end{array}$ & $\begin{array}{c}\text { Toplam } \\
\text { Mevduatlar }\end{array}$ & \multicolumn{2}{|c|}{$\begin{array}{l}\text { Toplam Öz } \\
\text { kaynaklar }\end{array}$} & $\begin{array}{l}\text { Şube } \\
\text { Sayisı }\end{array}$ & \begin{tabular}{|c} 
Çalışan \\
Sayısı
\end{tabular} \\
\hline$-0,324$ & $-0,319$ & $-0,325$ & \multicolumn{2}{|c|}{$-0,318$} & $-0,325$ & $-0,356$ \\
\hline$-0,368$ & $-0,367$ & $-0,367$ & \multicolumn{2}{|c|}{$-0,365$} & $-0,368$ & $-0,365$ \\
\hline$-0,337$ & $-0,335$ & $-0,317$ & \multicolumn{2}{|c|}{$-0,349$} & $-0,354$ & $-0,295$ \\
\hline$-0,232$ & $-0,235$ & $-0,241$ & \multicolumn{2}{|c|}{$-0,218$} & $-0,204$ & $-0,197$ \\
\hline$-0,240$ & $-0,268$ & $-0,241$ & \multicolumn{2}{|c|}{$-0,268$} & $-0,189$ & $-0,191$ \\
\hline 0,621 & & & & & & \\
\hline 0,933 & 0,947 & 0,926 & 0,944 & 0,8 & & 0,872 \\
\hline 0,067 & 0,053 & 0,074 & 0,056 & 0,1 & & 0,128 \\
\hline
\end{tabular}

Kaynak: Yazarın hesaplamaları.

Tablo 11: 2019 Yılı İçin Entropi Değerleri.

\begin{tabular}{|c|c|c|c|c|c|c|}
\hline \multicolumn{7}{|c|}{ Kriterlere İlişkin Entropi Değerleri } \\
\hline BANKALAR & $\begin{array}{c}\text { Toplam } \\
\text { Aktifler }\end{array}$ & $\begin{array}{c}\text { Toplam } \\
\text { Krediler ve } \\
\text { Alacaklar }\end{array}$ & $\begin{array}{c}\text { Toplam } \\
\text { Mevduatlar }\end{array}$ & $\begin{array}{c}\text { Toplam } \\
\text { Özkaynaklar }\end{array}$ & $\begin{array}{c}\text { Şube } \\
\text { Sayıs1 }\end{array}$ & $\begin{array}{c}\text { Çalışan } \\
\text { Sayısı }\end{array}$ \\
\hline Albaraka & $-0,309$ & $-0,318$ & $-0,309$ & $-0,305$ & $-0,318$ & $-0,359$ \\
\hline Kuveyt & $-0,368$ & $-0,367$ & $-0,367$ & $-0,364$ & $-0,368$ & $-0,364$ \\
\hline Finans & $-0,312$ & $-0,278$ & $-0,310$ & $-0,334$ & $-0,351$ & $-0,302$ \\
\hline Vakıf & $-0,239$ & $-0,251$ & $-0,236$ & $-0,217$ & $-0,214$ & $-0,233$ \\
\hline Ziraat & $-0,263$ & $-0,296$ & $-0,250$ & $-0,280$ & $-0,201$ & $-0,213$ \\
\hline 1/ln(m) & 0,558 & & & & & \\
\hline ej & 0,894 & 0,909 & 0,876 & 0,925 & 0,835 & 0,879 \\
\hline $\mathbf{d j}$ & 0,106 & 0,091 & 0,124 & 0,075 & 0,165 & 0,121 \\
\hline
\end{tabular}

Kaynak: Yazarın Hesaplamaları.

İlgili Entropi değerleri hesaplandıktan sonra son adım olarak Eşitlik (4) yardımıyla performans ölçümünde kullanılan kriterlere ilişkin kriter ağırlıkları hesaplanmıştır. Hesaplanan kriter ağırlıkları değerleri aşağıdaki Tablo 12' de verilmiştir. 
Tablo 12: 2018-2019 Yılları için Hesaplanan Kriter Önem Ağırlıkları.

\begin{tabular}{|c|c|c|c|c|c|c|}
\hline wj 2018 & 0,033 & 0,026 & 0,036 & 0,027 & 0,051 & 0,062 \\
\hline wj 2019 & 0,072 & 0,062 & 0,084 & 0,051 & 0,112 & 0,082 \\
\hline
\end{tabular}

Kaynak: Yazarın hesaplamaları.

2018-2019 yılları için hesaplanan kriter önem ağırlıkları Tablo 12' de en büyükten en küçüğe doğru ilk üçü sırasıyla; 2018 yılı için, birinci en önemli kriter olarak 0,062 değeriyle C1 kriteri, ikinci en önemli kriter olarak 0,051 değeriyle C5 kriteri olurken, son olarak üçüncü en önemli kriter olarak ise 0,036 değeriyle C3 kriteri gelmektedir. 2019 yılı için hesaplanan önem ağırlıkları sırasıyla; ilk en önemli kriter olarak 0,112 değeriyle C5 kriteri, ikinci en önemli kriter olarak 0,84 değeriyle C3 kriteri olurken0, üçüncü en önemli kriter olarak ise C6 kriteri 0,82 değeriyle belirlenmiştir.

Entropi değerlerinin belirlenmesiyle çalışmanın finansal performans analiz kısmının ilk bölümü tamamlanmıştır. Çalışmanın finansal performans analiz kısmının ikinci bölümünde ise Mairca yöntemiyle katılım bankalarının finansal performanslarının ölçümünün analizi yapılmıştır. Çok kriterli karar verme yöntemlerinin bir parçası olan karar matrisi analizin bu kısmında da kullanıldığı için Tablo 6 'da ve Tablo 7'de 2018-2019 yılları için oluşturulan karar matrisleri bu kısımda da kullanılmıştır.

Analizin ikinci kısmının ilk adımında karar alternatiflerinin öncelikleri Eşitlik (6) vasıtasıyla, 2018 yılı için $P_{A i}=\frac{1}{5}=0,20$ olarak, 2019 yılı için aynı değer $P_{A i}=\frac{1}{6}=0,17$ olarak hesaplanmıştır.

Çalışmanın analiz kısmının sonraki adımında ise Eşitlik (11) denkelmi ile 2018-2019 y1lları için teorik derecelendirme matrisleri elde edilmiştir. Söz konusu elde edilen matrisler 2018-2019 yılları için aşağıda Tablo 13' de ve Tablo 14'de gösterilmiştir. Bu adımda entropi yöntemi vasıtasıyla 2018-2019 yılları için elde edilen kriter önem ağırlıkları hesaplamaya dahil edilmiştir. 
Tablo 13: 2018 Yll İ çin Teorik Derecelendirme Matrisi.

\begin{tabular}{|l|c|c|c|c|c|c|}
\hline \multicolumn{7}{|c|}{ 2.Teorik Derecelendirme Matrisi (2018) (Tp) } \\
\hline $\mathbf{2 0 1 8}$ & maks & maks & maks & maks & min & min \\
\hline Alternatifler/Bankalar & $\mathbf{C 1}$ & $\mathbf{C 2}$ & $\mathbf{C 3}$ & $\mathbf{C 4}$ & $\mathbf{C 5}$ & $\mathbf{C 6}$ \\
\hline Albaraka & 0,007 & 0,005 & 0,007 & 0,005 & 0,010 & 0,012 \\
\hline Kuveyt & 0,007 & 0,005 & 0,007 & 0,005 & 0,010 & 0,012 \\
\hline Finans & 0,007 & 0,005 & 0,007 & 0,005 & 0,010 & 0,012 \\
\hline Vak1f & 0,007 & 0,005 & 0,007 & 0,005 & 0,010 & 0,012 \\
\hline Ziraat & 0,007 & 0,005 & 0,007 & 0,005 & 0,010 & 0,012 \\
\hline
\end{tabular}

Kaynak: Yazarın Hesaplamaları.

Tablo 14: 2019 Yılı İçin Teorik Derecelendirme Matrisi.

\begin{tabular}{|l|c|c|c|c|c|c|}
\hline \multicolumn{7}{|c|}{ 2.Teorik Derecelendirme Matrisi (2019) (Tp) } \\
\hline Alternatifler/Bankalar & maks & maks & maks & maks & min & min \\
\hline Albaraka & 0,012 & 0,010 & 0,014 & 0,009 & 0,019 & 0,014 \\
\hline Kuveyt & 0,012 & 0,010 & 0,014 & 0,009 & 0,019 & 0,014 \\
\hline Finans & 0,012 & 0,010 & 0,014 & 0,009 & 0,019 & 0,014 \\
\hline Vakıf & 0,012 & 0,010 & 0,014 & 0,009 & 0,019 & 0,014 \\
\hline Ziraat & 0,012 & 0,010 & 0,014 & 0,009 & 0,019 & 0,014 \\
\hline
\end{tabular}

Kaynak: Yazarın hesaplamaları.

Oluşturulan teorik derecelendirme matrislerinden sonra analizin bir diğer adımı olan gerçek değer matrisleri hesaplanmıştır. Bu işlem için Eşitlik (10)'dan yararlanılmıştır. Çalışmanın genel amacını oluşturan katılım bankalarının finansal performanslarının analizini gerçekleştirmek için kullanılan kriterleri ilk dördü C1, C2, C3, C4 kriterleri çalışmanın maksimizasyon yönlü kriterlerini oluştururken, C5 ve C6 kriterleri ise minimizasyon yönlü kriterlerini oluşturmaktadır. Maksimizasyon yönlü kriterlerin hesaplanmasında Eşitlik (14)'den, minimizasyon yönlü kriterlerin hesaplanmasında ise Eşitlik (15)'den yardım alınmıştır. 2018-2019 yılları için değerleri 
Entropi ve Mairca Yöntemiyle Türk Katılım Bankalarnın

Finansal Performans Siralaması

hesaplanan gerçek derecelendirme matrisleri aşağıda Tablo $15^{\prime}$ de ve Tablo $16^{\prime}$ da gösterilmiştir.

Tablo 15: 2019 Yılı İçin Hesaplanan Gerçek Derecelendirme Matrisi.

\begin{tabular}{|c|c|c|c|c|c|c|}
\hline \multicolumn{7}{|c|}{ Gerçek Derecelendirme Matrisi (Tr) } \\
\hline $\begin{array}{l}\text { Alternatifler/ } \\
\text { Bankalar }\end{array}$ & $\mathrm{C} 1$ & $\mathrm{C} 2$ & $\mathrm{C} 3$ & $\mathrm{C} 4$ & C5 & C6 \\
\hline Albaraka & 0,003 & 0,002 & 0,002 & 0,002 & 0,006 & 0,005 \\
\hline Kuveyt & 0,007 & 0,005 & 0,007 & 0,005 & 0,000 & 0,000 \\
\hline Finans & 0,003 & 0,003 & 0,002 & 0,004 & 0,003 & 0,009 \\
\hline Vakıf & 0,000 & 0,000 & 0,000 & 0,000 & 0,010 & 0,012 \\
\hline Ziraat & 0,000 & 0,001 & 0,000 & 0,001 & 0,010 & 0,012 \\
\hline $2018 \mathrm{Xij}+$ & 74.232 .325 & 44.168 .568 & 53.986 .278 & 5.438 .553 & 414 & 5.868 \\
\hline 2019 Xij- & 20.955 .512 & 13.321 .240 & 15.151.098 & 1.527 .226 & 80 & 1.042 \\
\hline
\end{tabular}

Kaynak: Yazarın hesaplamaları.

Tablo 16: 2019 Yılı İçin Hesaplanan Gerçek Derecelendirme Matrisi.

\begin{tabular}{|c|c|c|c|c|c|c|}
\hline \multicolumn{7}{|c|}{ Gerçek Derecelendirme Matrisi (Tr) } \\
\hline $\begin{array}{c}\text { Alternatifler/ } \\
\text { Bankalar }\end{array}$ & C1 & $\mathrm{C} 2$ & C3 & C4 & C5 & C6 \\
\hline Albaraka & 0,005 & 0,005 & 0,006 & 0,004 & 0,009 & 0,001 \\
\hline Kuveyt & 0,012 & 0,010 & 0,014 & 0,009 & 0,000 & 0,000 \\
\hline Finans & 0,005 & 0,004 & 0,006 & 0,006 & 0,005 & 0,007 \\
\hline Vakıf & 0,003 & 0,003 & 0,003 & 0,001 & 0,015 & 0,010 \\
\hline Ziraat & 0,003 & 0,004 & 0,003 & 0,003 & 0,015 & 0,011 \\
\hline $2019 \mathrm{Xij}^{+}$ & 104.439 .345 & 55.218 .449 & 85.494 .387 & 6.821 .290 & 430 & 4.120 \\
\hline 2019 Xij- & 9.282 .271 & 5.730 .333 & 5.952 .676 & 1.169 .173 & 11 & 381 \\
\hline
\end{tabular}

Kaynak: Yazarın hesaplamaları.

Gerçek derecelendirme matrislerinin de hesaplanmasından sonra analizin bir diğer adımı olan diğer adımı olan toplam boşluk matrislerinin hesaplanmasına geçilmiştir. Bu adımın hesaplanmasında ise Eşitlik (14)'den yararlanılmıştır. Elde edilen 2018-2019 yılları için 


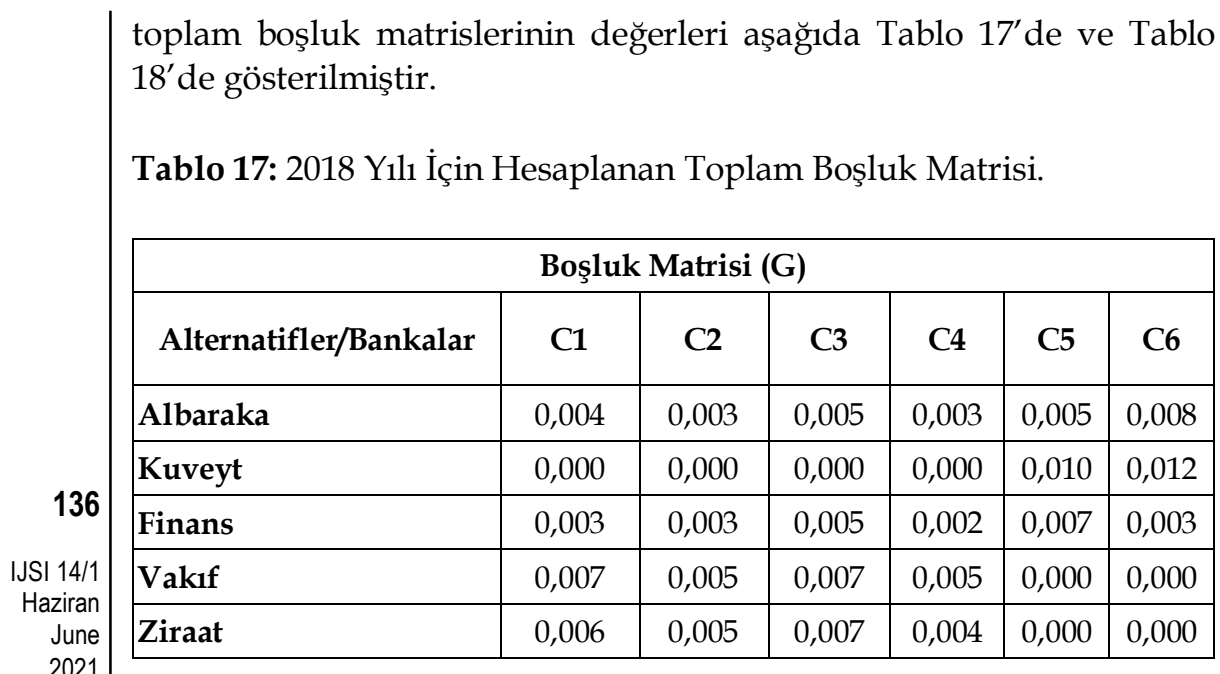

Kaynak: Yazarın Hesaplamaları.

Tablo 18: 2019 Yılı İçin Hesaplanan Toplam Boşluk Matrisi.

\begin{tabular}{|l|c|c|c|c|c|c|}
\hline \multicolumn{7}{|c|}{ Boşluk Matrisi (G) } \\
\hline Alternatifler/Bankalar & C1 & C2 & C3 & C4 & C5 & C6 \\
\hline Albaraka & 0,007 & 0,005 & 0,008 & 0,005 & 0,010 & 0,012 \\
\hline Kuveyt & 0,000 & 0,000 & 0,000 & 0,000 & 0,019 & 0,014 \\
\hline Finans & 0,007 & 0,007 & 0,008 & 0,003 & 0,013 & 0,007 \\
\hline Vakıf & 0,009 & 0,008 & 0,011 & 0,007 & 0,004 & 0,003 \\
\hline Ziraat & 0,009 & 0,006 & 0,011 & 0,005 & 0,004 & 0,003 \\
\hline
\end{tabular}

Kaynak: Yazarın hesaplamaları.

Toplam boşluk matrislerinin 2018-2019 dönemi için hesaplanmasından sonra analizin son adımı olan karar birimlerinin nihai (son) kriter fonksiyon değerlerinin hesaplanmasına geçilmiştir. Toplam Boşluk matrislerinden faydalanılarak Eşitlik (15) yardımı ile karar birimlerinin nihai kriter fonksiyon değerleri hesaplanmıştır.

Söz konusu değerler hesaplandıktan sonra ise, elde edilen nihai (son) kriter fonksiyon değerleri Mairca yönteminin bir parçası olan küçükten büyüğe doğru sıralanmış ve katılım bankalarının finansal 
performanslarına ait sıralamalar yapılmıştır. Aşağıda Tablo 19 'da hesaplanan nihai (son) fonksiyon değerleri ve 2018-2019 yıllarına ait finansal performans değerlerinin sıralaması gösterilmiştir.

Tablo 19: Son Fonksiyon Değerleri ve Performans Sıralamaları.

\begin{tabular}{|l|c|c|l|c|c|}
\hline \multicolumn{3}{|c|}{2018} & \multicolumn{3}{c|}{$\mathbf{2 0 1 9}$} \\
\hline Bankalar & Qi & Siralama & Bankalar & Qi & Siralama \\
\hline Albaraka & $\mathbf{0 , 0 2 6 8 1 6 5}$ & $\mathbf{5}$ & Albaraka & $\mathbf{0 , 0 4 6 4 2 8 1}$ & $\mathbf{5}$ \\
\hline Kuveyt & 0,0225871 & 3 & Kuveyt & $\mathbf{0 , 0 3 2 3 8 7 5}$ & $\mathbf{1}$ \\
\hline Finans & 0,0225757 & 2 & Finans & 0,0443389 & 4 \\
\hline Vakıf & 0,0246567 & 4 & Vakıf & 0,0428347 & 3 \\
\hline Ziraat & $\mathbf{0 , 0 2 2 4 7 4 6}$ & $\mathbf{1}$ & Ziraat & 0,0371037 & 2 \\
\hline
\end{tabular}

Kaynak: Yazarın hesaplamaları.

Tablo 19'da görüldüğü gibi 2018 ve 2019 yılları için katılım bankalarının finansal performans analiz edilip sıralanmıştır. Bu kapsamda 2018 yılına bakıldığında performans analizine dâhil edilen beş banka için en iyi üç banka sırasıyla; birinci en iyi performansa sahip katılım bankası Ziraat Katılım Bankası, ikinci en iyi performansı sergileyen katılım bankası Türkiye Finans Katılım Bankası, üçünü en iyi performansa sahip katılım bankası ise Kuveyt Türk Katılım Bankası olarak belirlenmiştir.

2019 yılına ilişkin bakıldığında ise, analize dahil edilen altı banka için en iyi üç banka sırasıyla; birinci en iyi performansa sahip katılım bankası Kuveyt Türk Katlım Bankası, ikinci en iyi performansı sergileyen katılım bankası Ziraat Katılım Bankası olurken, üçünü en iyi performansa sahip katılım bankası ise Vakıf Katılım Bankası olarak belirlenmiştir.

Çalışmanın analizinde yapılan hesaplamalar neticesinde çalışmanın kapsamına giren 2018-2019 yıllarında en kötü finansal performansı sergileyen katılım bankası olarak Albaraka Türk Katılım bankası olduğu belirlenmiştir. 


\section{SONUÇ}

Katılım bankacılığı olarak bilinen İslami bankacılık 1980'li yıllarda Türkiye' de faaliyete başlayıp günümüzde gidererek payını artıran ve gelişen bir bankacılık türüdür. Katılım bankacılığı 1980'li yıllarda ülkemizde Özel Finans Kurumları (ÖFK) adı altında hizmet vermeye başlamış, 2005 yılında ise banka statüsü kazanarak bankacılık faaliyetlerini sürdüren bir sektördür. Türkiye' de bankacılık sisteminin tamamlayıcı bir unsuru olan katılım bankacılığı sektörü hali hazırda pastadan aldığı payını her geçen gün daha da artırarak yoluna devam etmektedir.

Bu çalışmanın amacı Türk bankacılık sisteminde yer alan katılım bankalarının 2018-2019 yılları için finansal performanslarının çok kriterli karar verme yöntemlerinden olan Entropi ve Mairca yöntemlerinin entegre bir şekilde kullanılarak sıralanmasıdır. Bundan dolayı çalışmanın kapsamına giren yıllar için 5 adet katılım bankası analiz kapsamında incelemeye alınmıştır. Söz konusu bankaların finansal performanslarının ölçümünde kullanılan kriterler ise; Toplam Aktifler, Toplam Krediler ve Alacaklar, Toplam Mevduatlar, Toplam Öz kaynaklar, Şube Sayısı ve Personel Sayısı olarak belirlenmiştir.

Analizin birinci kısmında çok kriterli karar verme yöntemlerinden (ÇKKV) objektif grupta bulunan Entropi yöntemi kullanılarak analizde kullanılan kriterlerin önem ağırlıkları belirlenmiştir. Kriterlerin önem ağırlıkları Entropi yöntemi kullanılarak belirlendikten sonra çalışmanın analizinin ikinci kısmı olan Mairca yöntemi kullanılarak katılım bankalarının finansal performansları belirlenmiştir. Bu kapsamda 2018 yılına bakıldığında performans analizine dahil edilen beş banka için en iyi üç banka sırasıyla; birinci en iyi performansa sahip katılım bankası Ziraat Katılım bankası, ikinci en iyi performansı sergileyen katılım bankası Türkiye Finans Katılım bankası, üçünü en iyi performansa sahip katılım bankası ise Kuveyt Türk Katılım bankası olarak belirlenmiştir.

2019 yılına ilişkin bakıldığında ise, analizine dahil edilen altı banka için en iyi üç banka sırasıyla; birinci en iyi performansa sahip katılım bankası Kuveyt Türk Katılım bankası, ikinci en iyi performansı sergileyen katılım bankası Ziraat Katılım bankası olurken, üçünü en iyi performansa sahip katılım bankası ise Vakıf Katılım bankası olarak 
Entropi ve Mairca Yöntemiyle Türk Katılım Bankalarnın

Finansal Performans Siralaması

belirlenmiştir. Yapılan hesaplamalar neticesinde çalışmanın kapsamina giren 2018-2019 yıllarında en kötü finansal performansı sergileyen katılım bankası olarak Albaraka Türk Katılım bankası olduğu belirlenmiştir.

Çalışmanın yapıldığı dönem itibariyle, literatürde Mairca yöntemiyle yapılan çalışma çok sınırlı olduğu için, (sadece Ayçin ve Orçun $\left.(2019)^{2}\right)$, ileride yapılacak olan çalışmalara ışık tutması ve literatürdeki boşluğa katkı yapacağı düşünülmektedir. Ayrıca ileride yapılacak çalışmalarda, farklı kriterler belirlenerek, farklı sonuçların elde edilmesi muhtemeldir. Seçilen dönemler, seçilecek olan kriterlerin farklılaşması ve entegre bir şekilde farklı çok kriterli karar verme yöntemleriyle veya Mairca yöntemiyle yapılacak çalışmaların, katılım bankalarının finansal performanslarında farklı sonuçların çıkması, muhtemel sonuçlardandır.

2 Konvansiyonel/Ticari Bankalar için yapılmış bir çalışmadır. 


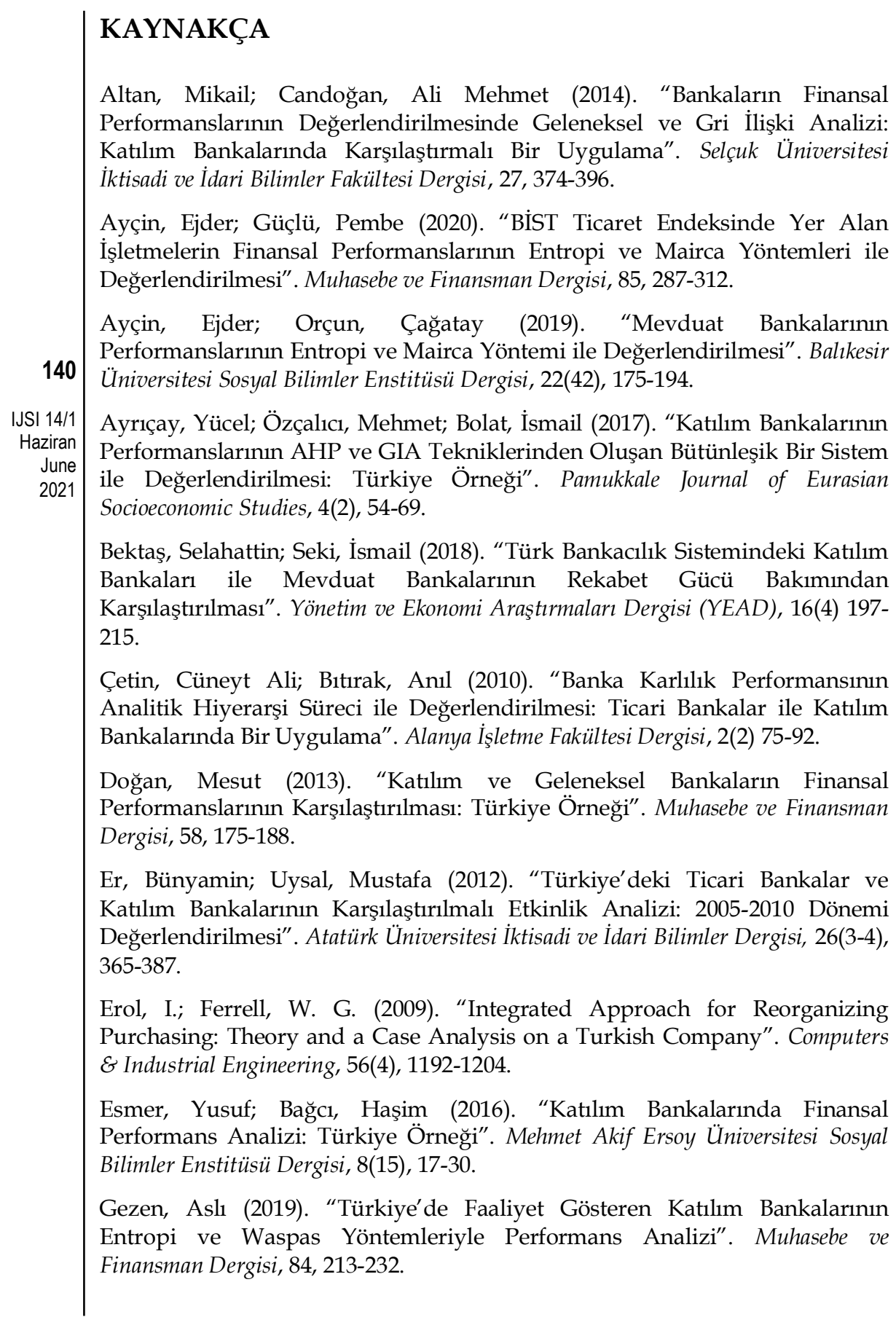




\section{Entropi ve Mairca Yöntemiyle Türk Katılım Bankalarnın \\ Finansal Performans Stralamast}

Gigović, L.; Pamučar, D.; Bajić, Z.; Milićević, M. (2016). “The Combination of Expert Judgment and Gis-Mairca Analysis for the Selection of Sites for Ammunition Depots". Sustainability, 8(4), 1-30.

Gümüş, B. Fatih; Nalbantoğlu, Öner (2015). “Türk Bankacılık Sektörünün Camels Analizi Yöntemiyle 2002-2013 Yılları Arasında Performans Analizi". Afyon Kocatepe Üniversitesi İktisadi ve İdari Bilimler Fakültesi Dergisi, 17(2), 83106.

Gündoğdu, Aysel (2018). “Türkiye'de Katılım Bankalarının Finansal Performanslarının Gri İlişkisel Analizi ile Ölçülmesi". Uluslararası İktisadi ve İdari İncelemeler Dergisi, (17. UIKK Özel Say1), 201-214.

Karavardar, Alper; Çilek, Arif (2020). “Türkiye'de Katılım Bankalarının Finansal Performansınin Analizi". Maliye ve Finans Yazlları, 113, 99-118.

Kaya, Ömer (2010). Katılım Bankacılığının Gelişimi ve Türk Bankacılık Sistemi İçerisindeki Etkinliğinin Araştırılması, (Yayımlanmamış Yüksek Lisans Tezi), İstanbul Üniversitesi Sosyal Bilimler Enstitüsü, İstanbul.

Kendirci, Çağıran Hülya; Kendirci, Selçuk; Aydın, Yasemin (2019). “Küresel Kriz Çerçevesinde Katılım Bankalarının ve Ticari Bankaların Mali Performanslarının Topsis Yöntemiyle Analizi". Atatürk Üniversitesi İktisadi ve İdari Bilimler Dergisi, 33(1), 137-154.

Özdağoğlu, A.; Yakut, E.; Bahar, S. (2017). "Machine Selection in a Dairy Product Company with Entropy and SAW Method Integration". Dokuz Eylül Üniversitesi İktisadi ve İdari Bilimler Fakültesi Dergisi, 32(1), 341-359.

Özgür, Ersan (2008). "Katılım Bankalarının Finansal Etkinliği". Afyon Kocatepe Üniversitesi İktisadi ve İdari Bilimler Fakültesi Dergisi, 10(1), 159-175.

Pamucar, Dragan S.; Tarle, Snezana Pejcic; Parezanovic, Tanja (2018). “New Hybrid Multi-Criteria Decision-Making Dematel-Mairca Model: Sustainable Selection of a Location for the Development of Multimodal Logistics Centre". Economic Research-Ekonomska istraživanja, 31(1), 1641-1665.

Pamučar, D.; Mihajlović, M.; Obradović, R.; Atanasković, P. (2017). “Novel Approach to Group Multi-Criteria Decision Making based on Interval Rough Numbers: Hybrid Dematel-Anp-Mairca Model". Expert Systems with Applications, 88, 58-80.

Sümer, Gökhan; Onan, Fatih (2015). “Dünyada Faizsiz Bankacılığın Doğuşu, Türkiye'deki Katılım Bankacılığının Gelişme Süreci ve Konvansiyonel Bankacılıktan Farkları". Gazi Üniversitesi İktisadi ve İdari Bilimler Fakültesi Dergisi, 17(3), 296-308.

Tetik, Nevzat; Şahin, Ahmet (2020). “Katılım Bankalarının Finansal Performans Analizi". Atatürk Üniversitesi İktisadi ve İdari Bilimler Dergisi, 34(2), 293-314. 
Wang, T. C.; Lee, H. D. (2009). “Developing a Fuzzy TOPSIS Approach Based on Subjective Weights and Objective Weights". Expert Systems with Applications, 36(5), 8980-8985.

Yayar, Rüştü; Baykara, Velid Halid (2012). “Topsis Yöntemi ile Katılım Bankalarının Etkinliği ve Verimliliği Üzerine Bir Uygulama". Business and Economics Research Journal, 3(4), 21-42.

Yurttadur, Mustafa; Demirbaş, Hayati (2017). “Türkiye'de Bulunan Katılım Bankaları ve Özel Sermayeli Mevduat Bankalarının Finansal Performanslarının Karşılaştırılması". İstanbul Gelişim Üniversitesi Sosyal Bilimler Dergisi, 4(2), 89-117.

Zhang, Hong; Gu, Chao-Lin; Gu, Lu-Wen; Zhang, Yan (2011). “The Evaluation of Tourism Destination Competitiveness by TOPSIS \& Information Entropy - A Case in the Yangtze River Delta of China". Tourism Management, 32(2), 443-451. https://www.tkbb.org.tr/

https://www.turkiyefinans.com.tr/ 


\section{Entropi ve Mairca Yöntemiyle Türk Katılım Bankalarnın \\ Finansal Performans Stralamast}

\section{SUMMARY}

The bank and the banking sector, which act as bridges in connecting the real sector and the financial sector, still remain an important issue for analysis in macroeconomic sense. The banks, which take the lead in the process of transferring their deposits to optimal investments without any problems, which have the savings or excess funds idle, have become very important for the economic performance and competition at the macro level as well as the banking sector. Participation banking, also known as Islamic banking, is also referred to as interest-free banking. These banks were born because of interest in people who are sensitive to interest and sensitive to belief. Participation banks perform their transactions on the basis of the interest-free principle while performing their banking transactions. These banks provide the required deposit to those with a shortage of deposits and perform a brokerage duty.

The participation banking sector in Turkey began operations in the 1980s. Since they were not in bank status at that time, they operated under the name of private financial institutions. However, since 2005, its name has been changed to participation bank and they continue their activities by gaining bank status. There are 6 participation bank in Turkey in 2019. Participation banking is a complementary element of the Turkish banking sector. State participation banks were established and the balances changed when the government took over this sector. In this context, it has become important to measure the performances of the participation banks in the Turkish banking sector based on the increasing competition environment with changing balances.

The founding date of participation banks in Turkey are as follows:

1985 Launch of Albaraka Finance and Faisal Finance Institution. 1989 Kuveyt Türk Evkaf financial institution started its operations. 1991 Anadolu Financial Institution commences its operations. 1995 İhlas Financial Institution commences its operations. 1996 The Asian Financial Institution commences its operations. 2001 Bankruptcy of the İhlas Finance Corporation. 2001 The transfer of Faisal Finance and the launch of Family Finance. Family Finance 2005 's Finance merged with Anadolu Finance Participation Bank Turkey to take action. 2015 Ziraat Participation Bank became operational. 2016 Vakıf Participation Bank became operational. 2019 Emlak Participation Bank commences operations.

Therefore, the aim of this study is to measure and rank the participation banks in the Turkish banking sector between 2018-2019. Compiled table summary literature of the studies measuring the participation banks' 
performances will be given as the second part after the introduction part that forms the first part of the study. In the next section, data method and analysis section, where the performance analysis, which is the purpose of the study, is made, will be mentioned. In the last part, a general evaluation and the outcome of the study will be discussed. The analysis part of the study consists of two different methods. First, the weights of the participation banks included in the analysis with the Entropy method were calculated. These calculated weights were then added to the Mairca method used as the second method, and the performances of the participation banks were listed by calculating. According to the results of the analysis, it was calculated by using the entropy and mairca methods of the participation banks in the Turkish banking sector for 2018-2019 in an integrated manner. Accordingly, there are

In the first part of the analysis, the importance weights of participation banks within the scope of the analysis were calculated with the Entropy method in the objective group of multi-criteria decision-making methods. After the importance weights of the criteria were determined using the Entropy method, the financial performances of the participation banks were determined using the Mairca method, the second part of the analysis of the study. In this context, Ziraat Participation Bank is the top three best performing participation bank among the five participation banks included in the performance analysis in 2018, respectively. Participation has the second best performing bank in Turkey Finans Participation Bank. The third best performing participation bank was determined as Kuveyt Türk Participation bank. In terms of 2019, the top three banks for the six banks included in the analysis are respectively; While the first best performing participation bank was Kuveyt Türk Katlım bank, the second best performing participation bank was Ziraat Participation bank, the third best performing participation bank was determined as Vakıf Participation bank. As a result of the calculations made, it was determined that Albaraka Türk Participation Bank was the participation bank that displayed the worst financial performance in 2018 2019, which was included in the scope of the study.

With the opening of the Emlak participation bank in 2019, the third public participation bank was opened. Therefore, 5 participation banks were included in the analysis in 2018, while six participation banks were included in the analysis, three of which were private and the other three were public. 